\title{
3. 印刷画像処理システム
}

\section{小野 善 雄 $^{\dagger}$}

\section{1. まえがき}

印刷物は印刷機による印刷工程によって生産される が，印刷を行うためには，その前段階である製版工程 に扔いて印刷版を製作しなければならない。印刷版に は平版 (オフセット), 凸版, 凹版 (グラビア) の主要 な 3 つの版式があって, 今日では平版が断然優勢にな っているが，いずれにしろ印刷物を構成する文字（お よび線画）と画像とは伝統的に別々の工程に従って処 理されて, 製版工程の後半において統合されて印刷版 が作られるというやり方がとられてきた。

今日, 印刷版の多くは（一部の活版などを除いて）, 写真的な方法, すなわち写真製版法によって製作され ているが, 近年, 写真製版の分野には伝統的な純光学 的方法に代って電子的方法が普及するようになり，そ れらの電子的な写真製版法は最近コンピュー夕によっ て処理される面が多くなっている.

この傾向は製版のディジタル化と称することができ るが，それは前記の文字と画像について別々に発展し てきた、そして，製版に扔けるディジタル化した文字 処理と画像処理とは, 融合あるいは統合し始めつつあ る.ここでは, このような傾向を踏まえながら, 特に 製版に打ける画像処理用の機器・システムの最近の動 向について概観することとする.

\section{2. カラースキャナ}

前記の写真製版の電子化は，まずカラー製版の分野 において最も早く普及した，そこで本稿においても， まずカラースキャナから論じていくこととする．

カラースキャナは 1950 年代前半に初めて実用化さ れ ${ }^{1)}, 1960$ 年代に入って普及化が始まり, 当初は色調 修正機能を伴った連続調色分解を行うものであった． 1970 年代に入ってから, 色分解（色調修正を伴う）と

$\dagger$ 大日本スクリーン製造株式会社

"Image Processing Systems for Printing Reproduction" by Yoshio Ono (Dainippon Screen Mfg. Co., Ltd., Kyoto)
·同時に網かけを（縮小・拡大の実際上任意の倍率変換 をも伴って)行うことのできるダイレクトスキャナが, 前記の連続調スキャナに代って普及していき,さらに ダイレクトスキャナの網かけ方式としては, 当初普及 したコンタクトスクリーン式からドットジェネレータ (電子網点発生装置) 式へ移行していった.

今日では連続調スキャナはごく一部で,また，コン タクトスクリーン式ダイレクトスキャナはまだかなり それぞれ使用され続けてはいるが，メーカで製造され るカラースキャナは, 実際上すべてドットジェネレー 夕式ダイレクトスキャナになっている. 図1に，この 形式のカラースキャナの概略構成を示す.

ドットジェネレータの露光用光源としては, ほとん どすべての機種がレーザを用いているが，ごく一部に LED を採用した機種もある。レーザとしては, ほと んどすべての機種が $\mathrm{Ar}$ か $\mathrm{He}-\mathrm{Ne}$ のいずれか一方を 用いているが，ごく一部に $\mathrm{He}-\mathrm{Cd}$ を採用した機種も

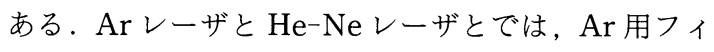
ルムと $\mathrm{He}-\mathrm{Ne}$ 用フィルムとの価格差のために $\mathrm{Ar} レ$

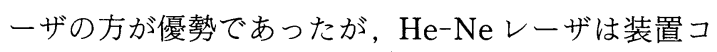
ストを始め種々の面で有利であり, 最近の両フィルム

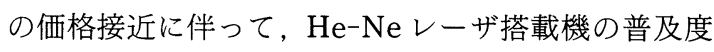
が高まっている.

ドットジェネレータの光学系についてみると, レー ザ光源とその光束を複数に分離・変調する光学系をス

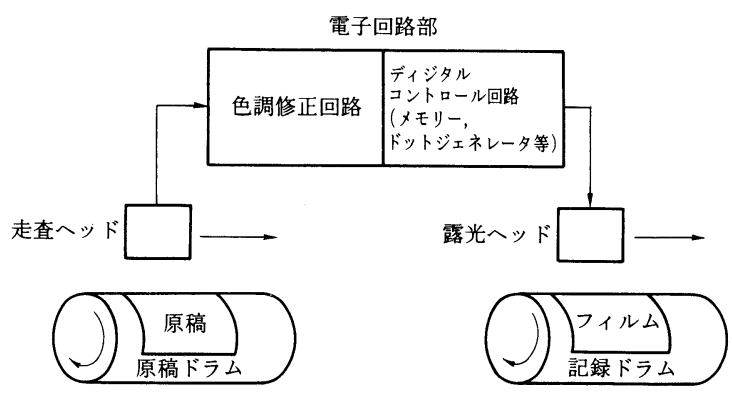

図 1 ドットジェネレータ式ダイレクトスキャナの概 略構成

テレビジョン学会誌 Vol. 42, No. 2 (1988) 


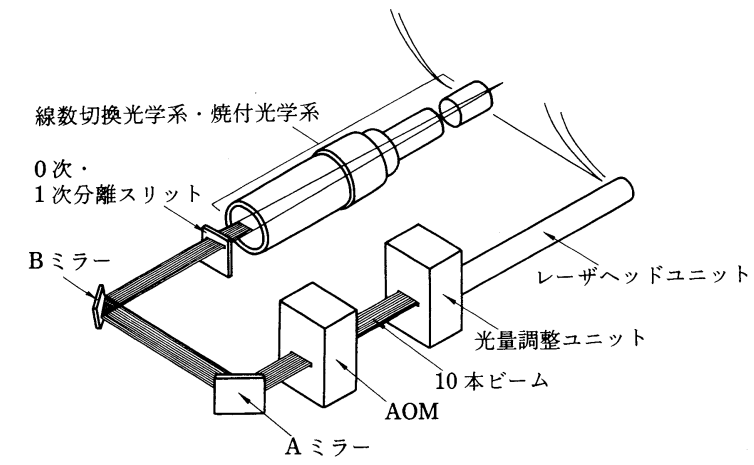

図 2 ドットジェネレータのレーザ内蔵型記録ヘッド の構成例（大日本スクリーン SG-608）

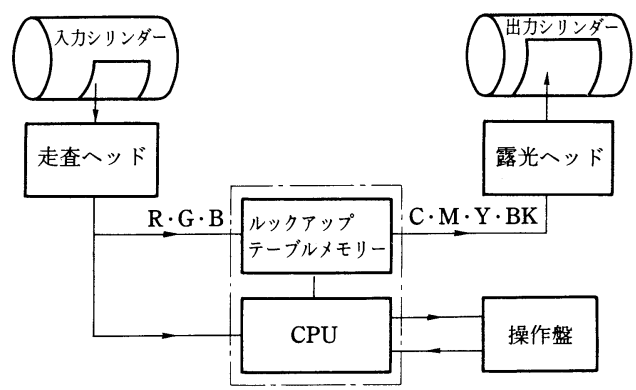

図 3 ルックアップテーブルメモリー式のディジタル スキャナの概略構成（Crosfield Magnascan 550)

キャナ本体とは別置きにし，その光学系と記録へッド との間を光ファイバでつないだ機種が最初発表さ れ2)，そのため, この形式のものが広く普及している が, 最近は記録へッド内にレーザを含むすべての光学 系を搭載した機種が増えている (図 2 参照).

前述の当初広く普及した機種においては, 分離した 光束の本数 (例えば 6 本) に対応する個数の光変調器 を用いているのに対して, 図 2 の系においては, 単一 の光変調器 $(\mathrm{AOM})$ により 10 本の光束を網点信号に したがって独立にオンオフ変調している ${ }^{3)}$.なお， 1 本の光束を光変調器 $(\mathrm{AOM})$ に入れて, 複数本の光ビ 一ムに分離しながら，それらを独立にオンオフ変調す る形式のものも出現している4). また, 図 2 に示す装 置の場合のように, ドットジェネレータの個々の網点 の形成を, より多数の微小光点の集まりで行って網点 品質を高めたものが広がりつつある゙ ${ }^{32}$.

カラースキャナの走査形式については, その開発初 期にはいろいろな形式の機種が発表されたものの, 普 及期に入ってからは, すべての機種が原稿側・記録側 の両方共に回転シリンダ走查式を採用してきた。しか
し, 最近になって，CCD な゙の固体素子ラインイメ ージセンサを利用した平面走査形式が, カラースキャ ナの原稿走查用に一部で利用され始めており, さらに この形式の新機種の出現をみている.

他方, 記録側については, 後述の白黒スキャナ, 写 植機等に広く採用されている平面レーザ走查露光形式 は, 通常のカラースキャナ用としては, まだ採用され ていない.ただし, レイアウトシステムの出力用とし ては,この形式の機種もごく一部で利用され始めてい る.

カラースキャナの操作盤上での色調修正の設定（セ ットアップ) は, カラー印刷物の品質を決定する重要 な要因であるが, これを迅速, 適正に行えるようにす るためのスキャナセットアップ決定装置には，いろい ろな方式のものが発表されている.それらの方式とし ては, マイコン利用式, カラーモニタ参照式, 基準力 ラー原稿参照式, 原稿濃度分布参照式等が知られてい る.

まだ有用性を広く認められたものはないが, 最近関 心をもたれている方式としては, スキャナで原稿を粗 走査して得た画像信号に基づいて, カラーCRT モニ 夕に表示される印刷シミュレート画像を参照するも $の^{5)}$, 原稿画像の濃度分布情報に基づいて自動的にセ ットアップを決定するもの, マイコンを利用して発注 者の修正要望を含む種々の原稿条件の入力に応じてデ シジョンッリー式にセットアップを決めるもの,さら には AI (人工知能)を利用するもの等が挙げられる.

色調修正回路は, 多くの機種において依然としてア ナログ式が用いられているが, ルックアップテーブル (LUT) メモリー利用のディジタル式の機種も広がり つつある (図 3 参照) ${ }^{6}$. 一般に, カラースキャナは原 稿のカラー画像から入力する R, G, B 信号から 4 色印 刷版を表す C, M, Y, Bk 信号への変換 (色修正付き)を 直接的に行っているが, CIE の UCS 表色系すなわち $(u, v, L)$ 系でカラー画像の色度デー夕を表現し， カラーモニ夕を利用して色調修正を行い，この系から 出力用の $(\mathrm{C}, \mathrm{M}, \mathrm{Y}, \mathrm{Bk})$ 系へ LUT により変換するス キャナも出現している7). また, セットアップ決定に おいて, カラー原稿に忠実な画像をモニタに表示し, 色相, 明度, 彩度スケールによってモニ夕画像を制御 する方式と, LUTによる色修正とを結びつけた新た なシステムが最近提案されている8.

フルブラック形式のスミ版を用いて，3色版のイン キ使用量を（それに伴って 4 色合計のインキ量をも） 最小限に抑える印刷方法は, インキコストを節減で き, 印刷が容易で, 中性色成分の再現が容易等の利点 


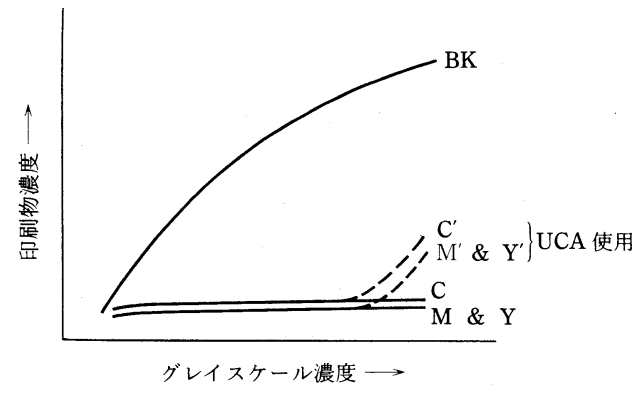

図 4 フルブラック形式 (GCR) によるカラー印刷物 の調子再現特性

がありながら，従来ほとんど利用されることがなかっ た．この方法が最近欧州を中心に改めて注目され，か なり実用されるようになっている $(\text { 図 } 4 \text { 参照 })^{9)}$. カラ 一スキャナの色調修正回路も, この方法をより適正, 容易に実施できるよう改良されている ${ }^{10)}$.この方法は unbunt Aufbau, achromatic printing 等と呼ばれた り，スキャナメーカ各社で種々の呼称がつけられたり しているが，米国で名付けられた GCR（gray component replacement）という呼び方が最近広がりつつ ある、

印刷物を構成する画像やその他の要素の一部に，色 調が均一な領域（平網あるいは平網ふせ）や所定の方 向に漸次変化する領域（ボカシ）を形成することが要 求される場合がある。これらは，従来各色版毎に指定 されたサイズ (面積率) の網点を有するスクリーンチ ント（ボカシの場合はグラデーションチント）を指定 された箇所に手作業で貼込んで，他の要素と共に多重 密着露光することによって形成されていた，最近にな つて，ドットジェネレータの機能を利用して平網やボ カシを自在に形成できるようにしたカラーグラデーシ ヨン発生装置が，スキャナの付属装置として実用化さ れている。また, 漫画, イラスト, 地図等々の作業に おいて，スキャナで入力された線画原稿をカラーモ二 夕で観察しながら, 閉曲線で囲まれた領域毎に指定さ れた色の平網ふせ処理を行い,ドットジェネレータに より出力記録する網ふせシステムも出現をみている。

次に述べるレイアウトシステムと従来からのカラー スキャナとの中間的存在として, カラースキャナに比 較的簡単な集版機能をもたせたものが最近出現してお り，コンポージングスキャナと呼ばれている。広い意 味でのコンポージングスキャナには，あらかじめカラ 一原稿を文字・線画と共に指定レイアウト通りに貼込 んだページ原稿を一括して走査, 色分解しながら, 文 字・線画をカラー画像よりも高解像に再現するという

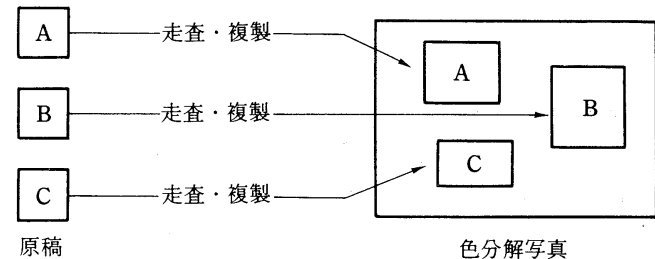

図 5 コンポージングスキャナの走查・複製の態様

形式のものもある。しかし，図 5 に示すような作業形 式をとる本来の狭義のコンポージングスキャナがかな り実用されつつあるので，ここではそれについて詳し く述べる.

コンポージングスキャナは，通常のカラースキャナ と同様に各カラー原稿を個別に走査するので，通常の スキャナと同じ個別色分解を行うこともできるが，コ ンポージング作業を行う場合には，あらかじめ各原稿 毎にトリミングとフィルム上での出力位置を所望レイ アウトに従って指定しておくことにより，複数の原稿 からの色分解画像をレイアウト通りに集版された状態 に直接記録することができる (図 5 参照)。また，画像 の枠付け，平網ふせ等の機能ををも併せ備えている.

コンポージングスキャナは，また最近のカラースキ ヤナの自動化の傾向を代表するものであり，1ページ の印刷物を構成するすべての画像について，各原稿毎 に倍率, トリミング, 出力位置, 色調修正等々の製版 条件の設定をあらかじめすべて指定しておき（単純な 個別分解の場合も含む)，スタートボタンを押すと， 後は機械がすべての原稿の走査・記録をマイコン制御 により次々に自動的に行うという機種が実用化されて いる ${ }^{11)}$. この場合，スキャナ本体と別置きにしたステ ーションで製版条件の設定を行うようにすると，スキ ヤナの稼動率を向上させることができる.

この種のステーションに㧍いて，原稿のトリミング の指定をスキャナ本体の走査座標系と同等の座標系で 行えるようにしたものも出現している ${ }^{12)}$. 加えて, 記 録側でのフィルムの装填, 排出, さらには自動現像機 への搬送までの動作の自動化も実現されている.

\section{3. レイアウトスキャナシステム}

レイアウトスキャナシステムあるいはレイアウトシ ステムは, 通常のカラースキャナの入力走査・色調修 正部と出力記録部との間で集版等の処理を行うコンピ ュー夕画像処理システムで, 従来手作業で行っていた 貼込みなどの集版作業をディジタル化して，集版処理 のスピード向上, 省力化, 材料節減等の効果をあげる ことを意図しており，現在の製版方法のディジタル化 


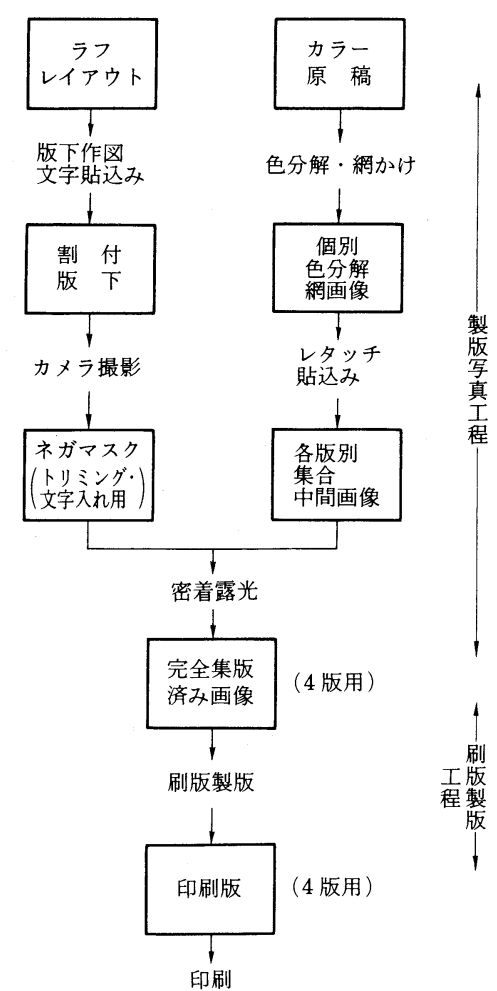

図 6 カラー製版の作業工程の概略

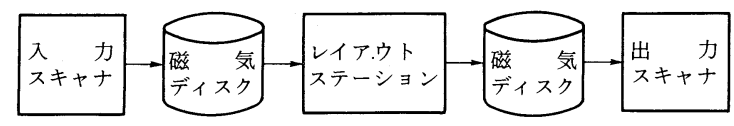

図 7 レイアウトスキャナシステムの概念的構成例

の傾向を代表するものといえる. 多くの場合, レイア ウトシステムは集版だけでなく追加修正の機能をも併 せ備えている. 従来の写真製版工程を示す図 6 に則し ていえば，レイアウトシステムは図中のレタッチ（追 加修正) 作業ならびに割付版下のカメラ撮影を含めて, 貼込みおよび密着露光から成る集版作業をディジタル 化するものである.

レイアウトスキャナシステムの構成を図 7 に概念的 に示す．それは，1つのページを構成する画像のカラ 一原稿をスキャナで次々に入力走査するときに, 色調 修正, 倍率変換の済んだ画像信号を従来のスキャナの ように直接出力露光する代りに, システムの磁気ディ スクにそれらをいったん格納する。磁気ディスクとし ては, 印刷画像に要求されるサイズと解像力と階調に 鑑みて, 多くの場合 $300 \mathrm{MB}$ 前後の容量のものが 1 単 位として用いられている（注：例えば A 3 サイズのカ ラー画像を 200 画素/ $\mathrm{cm}$, 各色版毎に 8 ビット/画素 でディジタル化すると，4色版で約 $200 \mathrm{MB}$ の情報量
を必要とする).

次に，レイアウト（あるいはメークアップ）ステー ションにおいては, ディスクからこれらの画像を順次 にCRT モニ夕画面に呼出して, 集版処理および必要 に応じて追加修正処理を施し，別のディスク（または 同一のディスク）に修正・集版済みの画像データを格 納する.この場合, モニタ上の処理は空間圧縮された 画像データについて施されることが多いので, 続いて ディスク内の実画像データ (本来の走査解像力をもつ たデータ）に対して同じ処理（実画像デー夕処理とか バックグラウンド処理などという）を施すことによっ て, 初めてディスク内に修正・集版済みデータが蓄え られることになる。

最後に, これらの集版済み画像デー夕はスキャナの 出力記録部に転送されて,フィルム上に集版済みの色 分解ページ画像が記録される。

なお，あらかじめ入力スキャナで粗走査した画像デ 一夕を用いて，指定レイアウトに従った画像の配置・ トリミングを決め，こうして決められた条件に従って 原稿の本番走査の際に磁気ディスク内にレイアウト済 み画像デー夕を直接格納していくという, 通常のレイ アウトシステムとコンポージングスキャナの中間的な 形式のシステムも最近出現をみている.

レイアウトシステムの画像処理の機能は, 前記のこ とから，追加修正用と集版用とに大別できる．これら の機能のうちの主なものを挙げると, 追加修正処理に は色調修正，スムージング，エアブラシング，移植等 があり，集版処理には図形の発生，位置決め，トリミ ング, 網ふせ, 切抜き, 画像の合成（はめ込み合成と すかし合成), 変倍, 回転等がある。これらの処理機 能の簡単な説明については, 他の文献を参照された ( $^{13)}$

レイアウトスキャナシステムの実際のシステム構成 としてはいろいろな形式のものがあり，それぞれの機 種にまた種々のバリエーションがある，例えば，比較 的早く発表されたもので，いくつかのステーション等 における作業の並行処理によってシステムの生産能力 を大きくとった形式のものがある ${ }^{14)}$. 最近は比較的安 価なシステムが増えており，それらについて以下に例 示する。

図 8 に示すのはそのようなシステムの一例の基本的 ブロック構成である。この構成においては，スキャナ 走査部から磁気ディスクへの個別画像の入力と, ディ スクからスキャナ出力記録部への集版済み画像の出力 とは, 同一の入出力ステーションを介して行われるの で，一時にいずれか一方の作業が行われるが，入力ス 


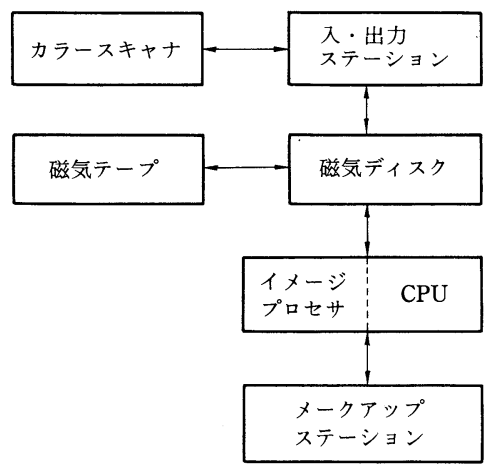

図 8 レイアウトスキャナシステムの構成例 (1) (大日本スクリーンシグマグラフシステム 6000 )

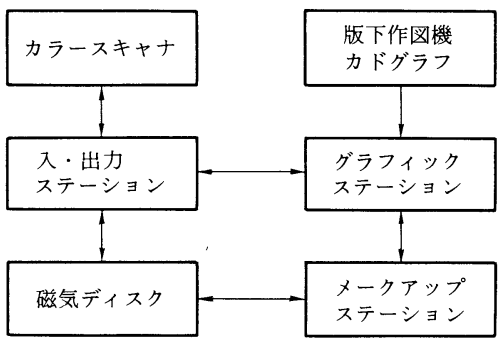

図 9 レイアウトスキャナシステムの構成例 (2) (大日本スクリーンシグマグラフシステム 3000)

テーションと出カステーションとを並設した構成とす れば，入力と出力の作業を同時に並行処理することが できる。

磁気ディスク装置を 1 組（2台）使用する場合，画 像の入力, 集版(および追加修正), および, 出力の各 作業は順次に行われて, この場合はいわばワンマン操 作ですべての作業を行うという作業形態になる．ディ スクは 4 組まで増設でき, 増設の程度に応じて並行処 理性を強化することができるが, さらに, モニ夕画像 処理と実画像処理との並行処理可能化などの機能の追 加が予定されている.

このシステムにおいては，別に設けた版下作図シス テムから，マスクデータと線画デー夕の供給を受ける ことができる．このシステムは，少人数のオペレータ で稼動させることができ，クリエーティブな仕事をも 含めて, 追加修正・集版のすべての仕事を効率良く実 行していけるのが特長といえるが，上記のようにシス テムの拡張性, 並行処理可能性が強化されつつある.

図 9 に別のシステムの基本的ブロック構成を示す. 図示の構成においては, 単一の入力ステーションと, より簡易なメークアップステーションとグラフィック ステーションという構成をとっていて，比較的安価な
構成でありながら，基本的に入力または出力と集版と マスク・線画デー夕処理の 3 つの作業を並行に処理す ることができる。磁気ディスクは基本 2 台で， 8 台ま で増設することができる．入力ステーションを別に設 けて入力の能力を強化することもできる．このシステ ムは基本的な集版機能を主体としていて，低価格で集 版作業用にコスト/性能の良いことを特長としている が, 主要な追加修正等の機能をも標準またはオプショ ン装備できる. 今後, このシステムについても機能の 拡充，並行処理可能性の強化が図られている.

レイアウトシステムが導入され始めた当初は, シス テム価格の問題もあって, これにより種々のクリエー ティブな画像を創り出せることが強調されたが，シス テムが本格的に普及しつつある現在では，やはりそれ が通常の集版作業を従来法よりどれだけ効率良く処理 できるかということが，最も主要な関心事となってき ている。

また, 将来の方向として，6 章に述べる直接製版機 との組合せによるカラー製版のコンピュータツープレ ートシステムへの発展が期待されている，そのために は, レイアウトシステムに文字が統合されることと， ディジタル色校正が組合わされることがまず必要であ り，すでにそのためのシステムまたはサブシステムが いくつか発表ないしは予告発表されている。これらに ついての方向または動向については別の文献を参照さ れたい ${ }^{15)}$.

\section{4. 白黒スキャナ}

カラースキャナの普及に伴って，単色製版において も, 特に品質要求レベルが高い場合にカラースキャナ を援用するということが行われるようになったが，専 用の白黒単色スキャナとして初めて成功した機種は 1970 年代半ばに出現したレーザ平面走査型のもので あった ${ }^{16)}$ 。もっとも，これは新聞主体の粗線スクリー

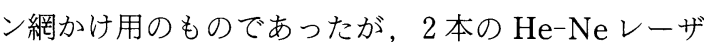
からの光ビームを, 原稿を走查するシャープ信号用ビ 一ム，アンシャープ信号用ビーム，タイミングパルス 発生用ビーム，および感材を露光する記録用ビームの 4 本に分離し，それらのビームを単一のがルバノメー タミラー（ガルボミラー）により偏向させて走查を行 うユニークな光学系を採用していた。

このスキャナでは, 従来の製版カメラによる網かけ に比べて, 網点は内蔵したドットジェネレータにより 電子的に発生され（後に発表された白黒スキャナもす ベてドットジェネレー夕搭載型となっている)，階調 の制御や鮮鋭度の強調を行うことができ, 装置サイズ 


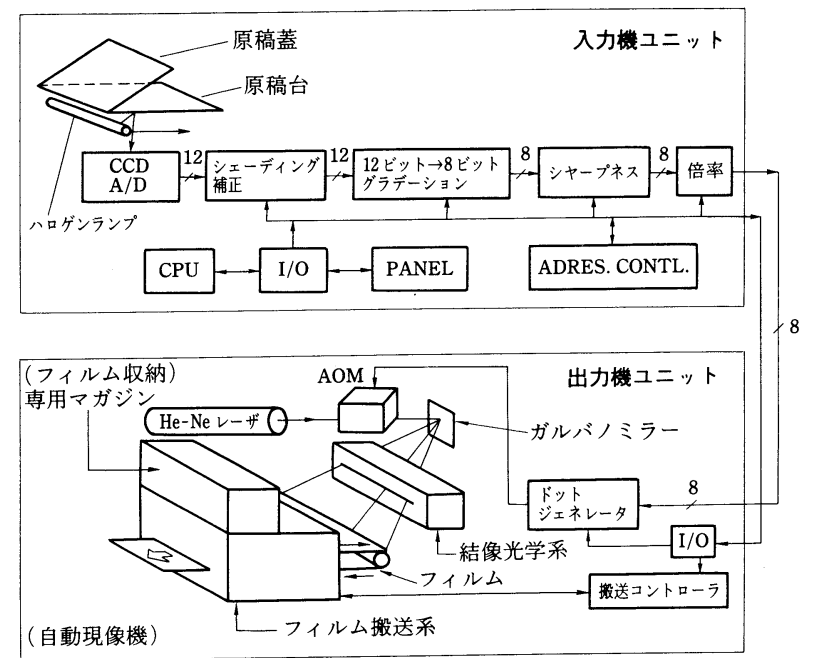

図 10 白黒平面スキャナの構成例(大日本スクリーン スキャニカ)

がコンパクトで, 操作性が良い, 等々の利点があっ て，かなりの普及をみせた．

1980 年代半ばになって, 細線スクリーンの網かけ ができる一般印刷用の白黒スキャナが出現した。この 種の機種の中で最初に実用化されたものは, $\mathrm{Ar}$ と $\mathrm{He}^{-}$ $\mathrm{Ne}$ の 2 種各 1 本のレーザを用いて, 感材露光用に Ar を使用するとともに, 両レーザで原稿走査を行っ て，カラー原稿からの白黒製版の場合に複製白黒画像 上での原稿の色に対応する明暗の階調の調整をできる ようにしている ${ }^{17)}$.この機種においても, 走査要素と しては原稿用と記録用の両方に単一のガルボミラーを 共用している.

さらに，原稿側では CCD ライセンサで入力走査を

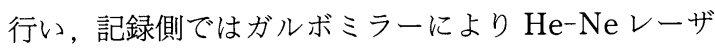
で出力走査を行う機種が実用化されたが，この機種の 構成は図 10 に示す通りで, 全面的なディジタル信号 処理, 走査スピードの速さ等を特長にしている ${ }^{18)}$. 原 稿走查用の CCD センサには, 5000 素子のもの 2 本を 用いている. CCD センサからの画像信号は, 図示の ように 12 ビットでシェーディング補正および階調制 御されて 8 ビットに変換され, それから, 鮮鋭度強調 や倍率変換を施されてドットジェネレー夕に送られ る.

最初に述べた新聞用機種の細線スクリーン化判の機 種, その他の白黒スキャナもあって, わずか $2 \sim 3$ 年 の間に一般印刷用の機種は急速に普及度を上昇させて いる。また他方では, 新聞用も含めて, 次章で述べる フルページ写植システムのための画像入力用, およ び, 場合によっては出力記録用に，これらの白黒スキ
ヤナの入力部または出力部をそれぞれ切離したよ うな形式の入力専用スキャナや, 出力専用スキャ ナも，特に米国を中心に普及しつつある. 入力ス キャナとしてはレーザ走查式の機種と CCD 走查 式の機種とがある。

\section{5. フルページ写植入出力機}

文字の処理を主体とした写真植字の領域におい ても，最初に述べたようにディジタル化，すなわ ちコンピュータ写真植字（電算写植）が近年進展 しており，それは扱うべき文字数の少ない欧米に おいてはすでに広く普及し，我が国でもかなりの 普及を示している. 電算写植の進展の過程の中 で, それは漸次線画やさらに画像をも含んだ完全 なフルページ組版のできるものへと発展していっ て, 今日そのような完全フルページ写植システム がゆっくりと広がりつつある.

この種のシステムにおいては, 画像（および線画） の入力スキャナの使用が必要である. 他方では, 電算 写植システムの出力機は当初の回転文字盤露光式の機 種から, より高速の CRT(特にオプチカルファイバチ ューブ）露光式の機種へと移行し, 最近はいっそうの 高速性を特長とするレーザ露光式の機種が普及しつつ ある。

まず，入力スキャナについてみると，これには前章 で述べたように, 白黒スキャナから入力部だけを切離 した形の機種が用いられ，レーザ走査式のものと $\mathrm{CCD}$ 走査式のものとがある.レーザ走查式の機種に

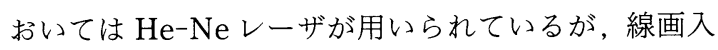
力用に必要な高い解像力を得ることが容易という利点 がある代りに, 白黒複製すべきカラー写真画像に対し て人間の眼と同様な階調認識ができないという久点が ある. $\mathrm{CCD}$ 走査式の機種はこれと反対の性質をもっ ているが, 受光 CCD の素子数および/または本数を 増やすことによって解像力の向上も可能であろう。な お,これらの画像入力用スキャナとは別に, ロゴ等の 入力用として CCD 式の小型のスキャナも利用されて いる.

写真植字用の出力機は英語で単に phototypesetter または typesetter と呼ばれるが, 最近のレーザ出力 機の普及化に伴って, 文字・線画だけを記録するので はなしに画像をも網点によって同時に記録できるよう になって, imagesetter と呼ばれることが多くなって きている．これらのレーザ写植機は，その記録用光源

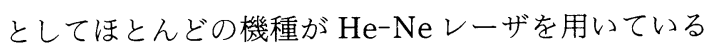
が, $\mathrm{He}$ - Cd または Arレーザを用いた機種もあり， 


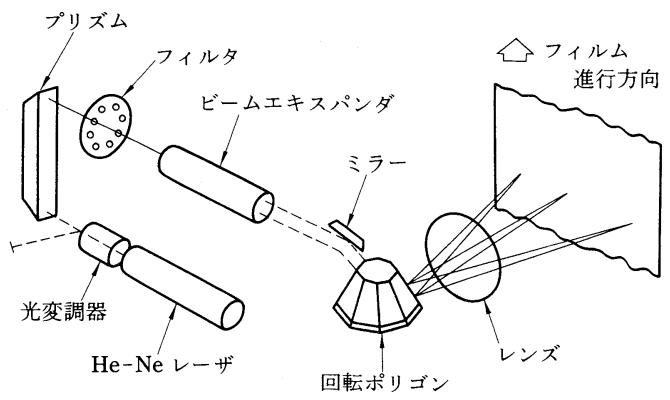

図 11 平面走查式のレーザ写植出力機の概略構成例 (Monotype Lasercomp)

最近は半導体レーザ用の製版感材の出現に伴って, 半 導体レーザを用いた機種も現れている。

また，走査形式としては，最初に実用化されたもの が He-Ne レーザビームをポリゴンミラーで感材上に 走査する平面走査式のもので (図 11 参照) ${ }^{19}$. この形 式を採用した機種が多いが，他にもガルボミラーやホ ロゴン（ホログラム回転板）による平面走査式の機種, 静止円筒内面走査式の機種，そして回転円筒走查式の 機種がある。また，レーザの他に，多数の LED を記 録用光源として用いた機種もあって，そのうちのある ものは機械的平面走査式を採用している.

なお，最近パーソナルコンピュータをべースにした 卓上出版システムが，社内印刷などの用途を主体に興 隆しつつあるが, これらのシステムに扔いては, 解像 カ 500 ドット/インチまでのレーザプリンタによって 電子写真で普通紙に出力を行うが（注：この種のプリ ン夕は通常の写真植字のための校正用にも普及しつつ ある), 同じ方式に基づいた 600 ドット/インチから 1200 ドット/インチぐらいまでの解像力の普通紙出力 機が米国で次々に発表されており, 今後この種の出力 機が中間的な品質の要求される市場に広がっていくと 予想されている ${ }^{20)}$.

写真植字のディジタル化は, コンピュータ組版化と 並んで，いま一面では文字フォントのディジタル化， すなわち, 回転文字盤からディジタルフォントへの移 行化によって進展しているが, 組版デー夕における文 字のコードデータを走査露光出力のためのラスタデー 夕に変換する作業は, 従来はコンピュータのソフトに よって行われていた。これを専用のハード回路によっ て高速に処理するラスタイメージプロセッサ (RIP) が 最近普及しつつあるが, RIP は文字データの変換だ けでなく, 線画デー夕のラス夕化と画像デー夕の網点 化の役目も担っていることが多い.

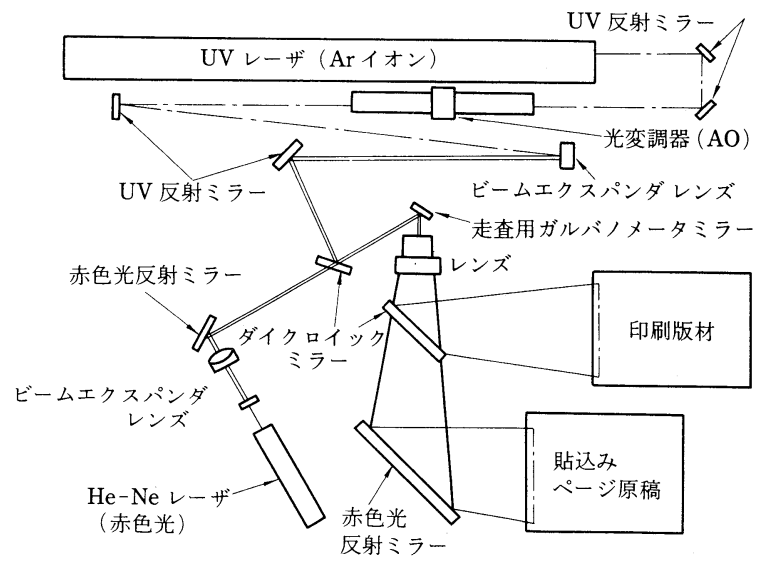

図 12 平面走査式の平版用レーザ製版機の概略構成 例 (EOCOM Laserite)

\section{6. 直 接製版機}

直接製版機とは，通常の写真製版においては，図 6 に示したように，製版写真と刷版製版という大別して 2 つの工程を必要とされるところを, 中間写真原板を 作成することなしに原稿から印刷版を直接製版する装 置である。

現在，軽印刷・事務印刷の分野においては，銀塩や 電子写真の高感度の平版版材（ペーパまたはプラスチ ックベース）を用いて，製版カメラでページ貼込み原 稿から直接露光することによって製版を行う直接製版 機が広く普及しているし，新聞印刷の分野において も，電子写真 $\mathrm{Al}$ 版材を用いる直接製版カメラが欧米 では部分的に利用されているが，一般印刷分野でのそ れらの普及度は低い。また，レーザ走査式の装置によ って, ページ貼込み原稿の走査と同期して版材を走査 露光する形式の直接製版機も，ごく一部で利用されて いる.

しかし，直接製版の今後の方向として期待されてい るのは, コンピュータッープレートシステムである。 これは, 文字と画像をそれぞれコンピュー夕処理して ディジタルデータの形で統合し, 中間フィルムを出力 することなしに，そのデー夕に基づいて印刷版を直接 製版するシステムである。この種のシステムは現在, ごく一部の分野において実用化が始まりつつある。こ の種のシステムで利用される直接製版機について, 平 版を主体に, 凸版, 凹版の各版式ごとに以下に述べ る。

平版用の直接製版機はレーザ走査露光形式をとる. この種のレーザ平版製版機は, 新聞用に上記した原稿 走查と同期して製版する形式のものが 1970 年代の半 
ばに開発され, 平面走査式のものと静止円筒内面走査 式のものがいくつか発表された.

レーザとしては, 高出力の Arレーザを用いる形式 のものと YAGレーザを用いるものとがあり, 前者が 多数を占めたが, これは従来法よりもずっと高感度の PS版またはワイプオン版（とはいっても, 銀塩や電 子写真の感材に比べるとずっと低感度のもの）を走査 露光するもので $(\text { 図 } 12 \text { 参照 })^{21)}$, 後者は感光層をもた ないアルミ版材に密着した特殊フィルムの露光部から 親油性物質層を版材面に転写させるものである ${ }^{22)}$.し かし，実際に設置された装置のうちで直接製版に利用 されるものは少数で, 多くは新聞ページファクシミリ 用に利用された。

そのうちに電子写真感光層を伴ったアルミベースの PS 版が出現して, 80 年代に入って直接製版機の改良 機種や新機種もいくつか発表されているが, 新聞分野 でのコンピュータッープレート化については, 米国で まず試みられた高出力 Arレーザ搭載機による実用化 が挫折し, 現在, 電子写真 PS版を利用する低出力 Arレーザによる実用化が 2 年ばかり前から始まって いる.

他方, 前章で述べたレーザ走査露光式のフルページ 写植出力機の普及化に伴い, 中間のフルページ写真画 像出力を省略して, この種の写植出力機をそのまま利 用して銀塩平版版材に直接製版を行うコンピュータツ ープレートシステムの実用化が, 一般印刷・軽印刷の 分野で最近になって始まっている. またごく最近, 赤 外増感した電子写真感光層を伴ったペーパまたは $\mathrm{Al}$ ベース版材と半導体レーザ利用の直接製版機の出現を みている。

凸版の一種であるフレキソ印刷版の分野において も, 原稿走査と同期して版シリンダを $\mathrm{CO}_{2} レ$ レ゙で 走查彫刻する回転円筒走查式の直接製版機が実用され ている ${ }^{23)}$.

凹版の中で断然広く利用されているグラビア印刷版 の分野においては, 中間ポジ画像の走査と同期して版 シリンダを機械的に走查彫刻する,やはり，回転円筒 走査式のグラビア䧓刻製版機が 1960 年代から実用さ れている ${ }^{24)}$. 最近になって, コンピュータ製版データ をこの製版機の出力側に直接送って, 中間画像を省略 して, 直接製版するコンピュータッーシリンダシステ ムが実用化され始めている.

なお, 通常の $\mathrm{Cu}$ 表面層の代りにプラスチック層を 伴ったシリンダを用いて $\mathrm{CO}_{2}$ レーザで走査彫刻を行 う直接製版機も, 最近実用化されている ${ }^{25)}$. さらに, $\mathrm{Cu}$ 層を伴ったシリンダに電子ビームで走査彫刻を行
う直接製版機が最近開発されている ${ }^{26)}$.

\section{7.むす び}

以上に述べたように，印刷製版における画像の形成 は, 伝統的な純光学的方法から電子的方法へと大きく 移行しつつあり, 特に最近コンピュータを利用したデ イジタル的方法へと発展しつつある.このような方法 による印刷製版機器は, 電子出版システムと呼ばれる ことも多い. 特に最近では, 社内印刷用などの安価な システムが卓上出版（デスクトップパブリッシング） システムと呼ばれて, 米国を始めとして急速に普及し つつある。

一般印刷用においても，上記したディジタル製版シ ステムは, カラー分野のレイアウトシステムと白黒分 野のフルページ写植システムを中心にして, 普及度を 上昇させつつある。ささらに, この種のシステムは中間 写真フィルム画像を省略した直接製版システムへと発 展しようとしており, 今後比較的構成の簡単な印刷物 から始まって複雑なものへと, この種の直接システム が漸次普及していくものと思われる.

これによって，いままですでに大きく改善されてき た製版工程は, 今後もなお生産性が向上し, 時間短縮 されていくことになると考えられる。

(昭和 62 年 11 月 2 日受付)

\section{〔参 考 文 献〕}

1) N. Bishop: "The Time-Springdale Colour Scanner" Penrose Ann., 45, pp. 92-94 (1951)

2）E.ヘニッグ:“クロマグラフ DC 300 型スキャナのエレクト ロニックダイレクトスクリーニング装置”，印刷雑誌， 57,5 pp. 3-11 (May, 1974)

3) Y. Nezu, Y. Tamura, Y. Mizuno, H. Iwamoto, A. Yokota and K. Maeda: "Multi-Beam Zoom and Focusing Lens Scan Pitch-Adjusting Recorder”, USP 4, 617, 578(Oct. 14 1986)

4) J. S. -Henning: "Elektronisches Umschaltem von Raster und Halbtonbetrieb mit neuer Belichtungseinheit $>\mathrm{KSK}\langle$ " Dtsch. Drucker, 21, 29, pp. 23-24 (Sep.19, 1985)

5) Anon. : "> Scanvision $\langle-$ ein neues Gerät zur Prüfung vor Scanner-Arbeitsergebnissen", Polygraph, 37, 3, pp. 200 \& 202(Feb. 5, 1984)

6) P. J. Wood: "New Development in Colour Scanning" Prof. Prin., 21, 1, pp. 2-4(Jan., 1977)

7) A. Masia :"A Digital Color Separating System Based or Principles of Colorimetry", Proc. TAGA 1984, pp.346-36]

8) W. F. Schreiber: "A Color Prepress System Using Appearance Variables", J. Imaging Technol., 12, 4, pp.20( -211 (Aug., 1986)

9）柏原, 太田: “ヨーロッパに扔けるスキャナ技法の新傾向” 印刷雑誌, 67, 4, pp. 39-44 (Apr., 1984)

10）坂本：“印刷における色再現一一ラースキャナを例とし て”, 日本印刷学会論文集, 23,3, pp. 123-129(Mar., 1986)

11）広沢, 畠山, 米丸, 藤井, 山田：“コンポージングスキャナ SC -777 のデー夕構造と制御”, 日本印刷学会第 77 回秋期研究発 表会予稿, pp. 59-62(1986) 
12）平岡：“ロボットスキャナとその効果”, 日本印刷学会第 75 回秋期研究発表会予稿, pp. 76-79(1985)

13）小野: “カラースキャナにおける画像処理”, 画像電子学会誌, 10, 5, pp. 398-406 (Dec., 1981)

14）小野：“シグマグラフシステム $2000 ”$, 印刷雑誌, $68,4, p p .9-$ 14 (Apr., 1985)

15）小野：“コンピュータ・ツウ・プレートシステムの展望一一画 像処理からのアプローチ”, 画像技術情報, 10, pp.2-9(Sep., 1987)

16) Anon.: "The ECRM Autokon Electronic Process Camera", Seybold Rep., 5, 8, pp. 1-8(Dec. 29, 1975)

W. F. Schreiber: "An Electronic Process Camera", TAGA Proc. 1983, pp. 701-727

17）星野：“「スキャナ」のすべて——ノクロスキャナ編”,pp. 110-119, 日本印刷技術協会, 東京 (1985)

18）小野：“「スキャナ」のすべて——モノロロスキャナ編”, pp. 100-109, 日本印刷技術協会, 東京 (1985)

19) D. Hedgeland: "Laser Typesetting-Text and Pictures", TAGA Proc. 1982, pp. 31-47

20) (D. R. Spencer : ) "Output Technologies and High Resolution”, Seybold Rep. Publ. Syst., 16, 11, pp.3-20 (Feb.16, 1987)

21) L. G. Larson: "Laserite, A New Development in
Platemaking”, TAGA Proc. 1975, pp. 109-119, "Important Considerations in Laser Imaging of Photosensitive Surfaces, ibid, pp. 334-344

22) R. W. Landsman: "The LogEscan Laser Platemaking System", TAGA Proc. 1977, pp. 1-11

23) D. Bennett and J. Webster: "The Zedco Rubber Roller Engraving Machine”, Proc. SPIE, 169, pp. 48-55(1979)

24) W. Baar and J. Dolves: "Application of Modern Electronic Techniques in Electronic Engraving of Gravure Cylinders", TAGA Proc. 1975, pp. 304-323

25) B. Jordan : "Progress in Lasergravure", TAGA Proc. 1982, pp. $48-57$

26) U. Gast : "EBG-The Electron Beam Engraving of Gravure Cylinders”, TAGA Proc. 1985, pp. 28-44

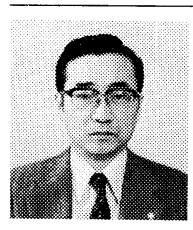

小野 善雄 昭和 30 年, 京都大学理学部 物理学科卒業. 同年, 大日本スクリーン製造 (㧣に入社. 同社にて, 研究, 調査, 企画, 開 発, 特許等の業務に携わり, 写真製版技術と 写真製版機器についての研究，開発等に従 事．現在，同社技術情報部長．

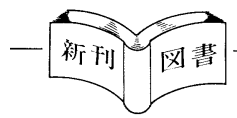

\section{情報・通信における ディジタル信号処理}

\section{村野和雄，海上重之 共著}

本書は，デー夕伝送と音声伝送を中心とする情報通 信におけるディジタル信号処理の解説であって, 次の 5 章からなる。

1. 序

2. データ伝送における信号処理

3. 音声のディジタル通信

4. キャセリング信号処理

5. 情報通信における信号処理の実現

書名は「情報・通信におけるディジタル信号処理」 であるが，情報分野は対象となっていない，その意味 では，書名の情報と通信の間の・は不要である。また， “まえがき”にもあるように，ディジ夕ル信号処理の基 楚的な事項はある程度マスターされている読者を前提
としている．

本書の特徵は，「通信におけるディジタル信号処理 をいかにハードウェアあるいはファームウェアとして 実現するか」という観点からの記述にある，特に，大 学に籍を扔く評者にとっては第 5 章が面白かった。

著者は, 我が国を代表するディジタル信号処理の研 究者であり，本書の内容も著者らの豊富な経験と研究 開発実績の裏付けがある。その意味で本書は安心して 読むことができるし，また，ディジ夕ル信号処理の実 際の応用を知りたい技術者, 大学院生に薦められる。

ただし，上記のように対象がデー夕伝送と音声伝送 に限られているので, 画像通信, 放送におけるディジ タル信号処理にはまったく触れられていない。この点 がテレビジョン学会員である評者には多少さびしかっ た。

紹介 原島 博（東大）

昭晃堂刊 (昭和 62 年 11 月 25 日発行), A 5 判 225 頁, 定価 3600 円 